\title{
African-Americans and Clinical Trials Research: Recommendations for Client Engagement
}

\author{
Sharon E. Moore \\ Wanda Lott Collins
}

\begin{abstract}
African-Americans have, without their knowledgeand consent, been used as human guinea pigs in scientific and medical experiments by private and governmental organizations. As a result many African-Americans approach thehealth care industry with caution and apprehension. African-Americans are admonished to remember theatrocities they onceexperienced and to approach participation in clinical studies with skepticism. This paper presents an historical overview of conspiracy theories, discusses various health issues that affect African-Americans, identifies for whom partici pation in clinical trials could provebeneficial, and recommends methodsthat can beused to attract African-American dientsasactiveparticipantsin clinical studies.
\end{abstract}

Keywords: African-Americans, conspiracy theories, clinical trials, research, patient rights

$\mathrm{M}$ any African-Americans approach the health care industry and especially medical researchers with caution and apprehension. Reese and Ahern (1999) found that many African-Americans fear they will "end up being a guinea pig in one of their experiments" (p. 554). Various conspiracy theories contribute to their trepidation

Although not all of the common conspiracy theories are rooted in fact, some are. Perhaps the most notable of these violations of human dignity occurred during the Tuskegee Syphilis Study. During this United States Public Health Service sponsored experiment, 107 of the 400 men who were involved died because they went untreated, even though penicillin had been proven to be effective in curing the disease (Fairchild \& Bayer, 1999). They had been lured to participate in the experiment under the promise that they would receive free medical care to cure a variety of medical ailments from which they suffered. Tuskegee is symbolic of unjust practices of the medical community, unethical practices in human research, and government mistreatment of African-American people. It has caused many African-Americans to be suspicious of the medical and public health authorities and is a major factor in low participation among African-Americans in human research (Gamble, 1997).

Another incident of unethical research involving African-Americans occurred in the 1970s. This well-publicized experiment was funded by the National Institute

Sharon E. Moore, Ph.D. is Associate Professor and Wanda Lott Collins, Ph.D. is Assistant Professor at the Raymond A. Kent School of Social Work, University of Louisville, Louisville, Kentucky.

Copyright 2002 Advances in Social Work Vol. 3 No. 1 (Spring 2002) 46-59.

Indiana University School of Social Work. 
of Health. In that study, blood samples were taken without parental consent from 7,000 young, underprivileged boys from the Baltimore area. They thought they were being tested for anemia (Washington, 1994). In actuality, they were screened to determine who among them had an extra " $Y$ " chromosome, under the assumption that individuals with an extra " $Y$ " chromosome were foreseeable criminal types. Many of these young men were later labeled criminals. These are two of many examples of deceptive research practices that have contributed to the "healthy paranoia" that exists among many African-Americans. The term healthy paranoia refers to a positive defense mechanism use by AfricanAmericans in recognizing that racism exists and that white people must be approached cautiously until they prove that they are trustworthy (Grier \& Cobbs, 1968).

\section{BELIEF IN CONSPIRACYTHEORIES}

Many of these theories assert negative actions by the government against AfricanAmericans. Turner (1993) indicates that theories of government conspiracy fall into two main categories: malicious intent, in which the government purposefully causes or increases social problems with African-Americans, and benign neglect, whereby the government takes a nonchalant attitude to addressing social problems. Other concerns focus on contamination theories that maintain that efforts are made to harm the health of African-Americans in various ways.

\section{Pervasiveness of Conspiracy Beliefs}

In a survey of 2,000 African American residents from Philadel phia and Charlotte, North Carolina, Turner and Darity (1973) found that up to $62 \%$ of the respondents believed that the U.S. government was trying to decrease the African American population. Parsons, Simmons, Shinhoster \& Kilburn (1999) conducted the first comprehensive empirical study of the beliefs of African-Americans on a number of theories that asserted governmental wrong doings. They found that of the 1,104 African-Americans questioned, most believed in conspiracy theories, particularly those involving government plots that target African-Americans. More than half responded that the government directs genocidal efforts towards AfricanAmericans. These beliefs are as common among African- American professionals as they are among nonprofessionals (Parsons, et al., 1999).

Among the common conspiracy theories held by African-Americans are that:

1. AIDS was developed by white scientists to be used as a form of AfricanAmerican genocide (Parsons, et al., 1999).

2. The National Centers for Disease Control was involved in the Atlanta child murders as part of an experiment to extract the cancer drug interferon from the tops of Black boys' penises (Harris, 1996).

3. The Ku Klux Klan has economic ties to Troop Sportswear, Church's Fried Chicken, and Tropical Fantasy fruit drink (Turner, 1993).

4. Illicit drugs are planted in the African-American community by the U.S. government for economic profit and as a form of racial genocide (Parsons, et al., 1999; McWhorter, 2000). 
5. The U.S. government purposefully investigates African-American elected officials in an effort to discredit them “in a way it doesn't do with white officials" (Ruffins, 1998, p. 27).

6. Norplant implants are a mechanism to permanently sterilize AfricanAmerican women (Turner, 1993).

7. The Sickle Cell Anemia screening program of the 1970s was a form of government directed genocide (Wilkinson, 1974).

\section{The Development of Conspiracy Theories}

What is known about these theories is that they began in response to the racism and mistreatment that African-Americans suffered during slavery. The Tuskegee Study brought to light unethical research practices that had occurred for centuries.

During slavery, both slaves and free African-Americans were routinely exploited by the medical profession. Their bodies were often used without consent for dissections and medical experimentation (Savitt, 1982). Following emancipation, stories of "night doctors" were common in the African-American community. Night doctor was the term applied to medical students who allegedly stole cadavers for training purposes and to professional thieves who sold living and dead AfricanAmericans to doctors who used them for medical research. In 1882, it was exposed that African-American cemeteries were frequently pillaged by grave robbers who later sold the corpses to Philadel phia medical schools (Thomas \& Quinn, 1993).

Hence, conspiracy theories have become a part of the collective consciousness of African-Americans and have been orally passed down through the informal grapevine for generations. Many African-Americans believe that that they are targeted for human experimentation because of their race. Subsequently, many African-Americans understandably approach the medical community with considerable apprehension. Belief in these theories is not necessarily pathological. Indeed, they may serve to solidify the community and move it toward social action. Being encouraged to approach participation in research with skepticism and as a conscientious consumer is positive because it is empowering. Alternatively, a negative consequence of this belief system is that AfricanAmericans do not benefit from legitimate research in areas such as mental health and medicine (Dhooper \& Moore, 2000).

Due in part to conspiracy beliefs, many African-Americans delay or postpone seeking medical treatment, which often has dire consequences for them. Numerous health problems disproportionately affect African-Americans. Effective treatment strategies for many of these conditions could be developed through clinical trials research that included African-American participants.

\section{HEALTH PROBLEMSAND AFRICAN-AMERICANS}

There are approximately 35.5 million African-Americans. They represent about 13\% of the United States population (U.S. Bureau of the Census, 2001). On average, AfricanAmericans livesix fewer years than whites (Thompson \& Chambers, 2000). Nearly 75 million of all Americans aged 12 and above report using illegal drugs at least once during their lifetimes (National Institute of Drug Abuse, 1998). Approximately $10 \%$ of these are African American. However, African-Americans make up approximately 
36\% of U.S. citizens who are drug dependent (National Institute of Drug Abuse, 1998). African-American women, more than others, have disproportionately higher rates of death from diabetes, cancer, cardiovascular diseases, and breast cancer. They are also more likely to struggle are substance abuse, addiction, HIV, and AIDS. AIDS is now the leading cause of death among African-American women between the ages of 25 and 44 years, representing a rate that is 12 times higher than that of their white counterparts (Kumanyika, Morssink \& Nestle, 2001; Phillips, 1997,). Generally, when they do present themselves for treatment, they are in more advanced stages of the disease and have more symptoms. Cultural beliefs, such as conspiracy theories, coupled with socioeconomic variables are responsible for late diagnosis (Kumanyika, Morssink \& Nestle, 2001; Raveis \& Siegel, 1998).

\section{Gender Specific Problems}

African American men are 76 times more likely than white men to die of a stroke related to high blood pressure (Dwyer, 1995). They have more problems with physical mobility after age 65 due to chronic diseases and have a 50\% higher rate of prostate cancer than white males (Herbert, Hurley, Olendzki, Teas, et al., 1998; Thompson \& Chambers, 2000). There are 2.8 million African-Americans over the age of 65 (U.S. Bureau of theCensus, 2000). Although African-American elderly are living longer, they are more likely to be infirm, have chronic diseases at earlier ages, and be more physically limited in these illnesses (Allen-Kelsey, 1998).

Clinical trials are vital in health research and the development of medical knowledge. They are the measure by which new therapies are investigated. "They allow investigators to test biological hypothesis in living patients and they have the potential to change thestandards of care" (Davidoff, et al., 2001, p. 854). Before 1994, most studies on the health of Americans conducted through academic medical facilities using human subjects that were middle-class, white male, or married. African-Americans were only minimally represented in these studies (Flaskerud \& Nyamathi, 2000). When they did participate, they were sometimes injected with cancerous cells and cancer-producing substances, subjected to lobotomies, or injected with hazardous materials (Dhooper \& Moore, 2000). As a result of limited, homogenous samples, research findings were sometimes erroneously generalized to the entire population without considering that cultural variables are important in diagnosing and treating health-related disorders in minority populations. Additionally, African-Americans are more susceptible to an increase in mortality and a decrease in quality of life when they are not included in health-intervention research. Current controls that exist to minimize past abuses include the National Research Act of 1974, which was passed after the Tuskegee study became public. This legislation established guidelines whereby all federally-funded research that involves human subjects requires prior approval from an institutional review board and a data monitoring committee that expeditiously identifies evidence of benefit or harm to research participants (Lilford, Braunholtz, Edwards \& Stevens, 2001). Other controls include the development of the Patient's Bill of Rights and the establishment of the National Institute of Health's Office of Research on Minority Health in 1990. The office of Research on Minority Health oversees biomedical and behavioral research on underrepresented minorities (Helmuth, 2000). Even though these controls are in place, African-Americans are still underrepresented 
in clinical trials. What follows are suggestions for ways in which African-Americans can be encouraged to participate in clinical research activities.

\section{PRESCRIPTIONSAND IMPLICATIONS FOR RESEARCH}

Lack of information, fear of experimentation, lack of familiarity with bureaucratic institutions, illiteracy, caregiver obligations, language barriers, and lack of benefits are several hindrances to research participation (Napoles-Springer, Grumbach, Alexander \&Moreno-John, 2000). Thequestion that begs an answer ishow can medical, public health, and social science researchers attract African-American volunteers to participate in research studies. Burrus, Liburd, and Burroughs (1998) document several strategies that can be useful in targeting and increasing African-Americans participation in future public health research. They suggest 1) hiring a community organizer; 2) establishing community advisory board; 3) soliciting community input; 4) scheduling public meetings for formal and informal question and answer sessions; 5) involving key African American personalities; and 6) including the black church.

Furthermore, they suggest approaches which can be used to eliminate barriers to participation and enhance trust among African-American research volunteers. Those approaches focus on: 1) community engagement; 2) explanations of the "why" and the "what"; 3) purposeful community relationships; and 4) non-traditional, culturally sensitive communications. What follows is a discussion of how these approaches can be implemented.

\section{Community Engagement}

One strategy that can be used to maximize medical research participation among African-Americans focuses on a model of community partnerships, which can be reflective of community needs, perspectives, and health priorities (NapolesSpringer, et al., 2000). There is agreement that community support is paramount in establishing credibility among researchers and minority groups (Hatchett, Holmes, Duran \& Davis, 2000; Mastin, 2000; Witte, Berkowitz, Lillie \& Cameron, 1998).

Burrus, et al. (1998) discuss the importance of informing the community about the proposed research to solicit their input. Hiring a well-known and respected African-American health educator is another significant factor in organizing. Equally important is the organizing of a community advisory board to serve as overseers for the community. Its purpose is to question the process and to ensure that the community will not be exploited. The advisory board provides the research team with easier entry into the African-American community and reduces what can be a time intensive process. Additionally, if at all possible, the research should be conducted in either the participants' community or an environment where they are most at ease. Furthermore, African-American recruiters or representatives who understand the task and can communicate the interest of both parties should be utilized.

The Black church is still the primary place where African-Americans congregate to address cultural, economic, and social issues. The impact and important role of the Black church in garnering and portraying the positive energy of AfricanAmerican families is also recognized by Mastin (2000) in her study of media use and civic participation in the African-American population. She wrote: 
The community church has long served as a facilitator of political action for African-Americans. The African-American church enjoys a historical reputation of working to improve members' socioeconomic and political conditions. Unlike many social organizations that draw attention to social differences, often excluding individuals based on economic differences, many Black churches do a good job of minimizing such differences. In short, the African-American church has been able to facilitate civic and political involvement among the economically diverse groups in the African-American community. (p. 117)

In essence, Mastin's (2000) findings clearly indicate that interpersonal relationships and church involvement are strong predictors of civic participation among African-Americans. This finding strongly suggests that including the Black church as a key player in significant community events is a well-conceived strategic move for researchers. Researchers have successfully approached African-American churches that have large memberships, to aid them in their mission to solicit African-American representation in public health studies (Burrus, et al., 1998; Hatchett, et al., 2000). However, researchers' recruitment efforts must be more than superficial to maximize the availability of the church as a resource. It is not enough to make an announcement and request help. Rather, individuals must be contacted and actively encouraged to participate (Hatchett, et al., 2000).

Additionally, onsite informational meetings should be held with representatives of the church to explain the goals and objectives of the study and to answer questions. Researchers would be wise to show sensitivity and take special care to address all questions to the satisfaction of potential participants with honest and forthright details. Schoen (1999) proposes “Giving investigators an opportunity to discuss their work with the public, through media interviews and community speaking engagements, can motivate them to becomemore personally involved in the product's trial, proving a compelling reason to prioritize it" (p. 52).

Another recommendation is to work closely with various community facilitators who have real and perceived positions of trust. These individuals can be recruited to encourage and lend an active voice for participation in research efforts. Given their high visibility within the African-American community, their collaboration with the research team may serve to enhance the validity of the study and heighten awareness regarding the importance of the study. In essence, they convey a seal of approval (Hatchett, et al., 2000).

Rather than researchers representing themselves as the community authority, the power of "knowing" is maximized when shifted to the people. An often overlooked fact is that African-Americans are weary of people who propose to know what is best for them (Hatchett, et al., 2000). Within the African-American community are resources, insights, and knowledge that are unknown to social science professionals (Saleeby, 1996). In defining the role of "expert" or "professional," Saleeby (1996) indicates that "a helper may best be identified as a collaborator or consultant: an individual clearly presumed, because of specialized education and experience, to know some things and to have some tools at ready but definitely not the only one in the situation to have relevant, even esoteric knowledge and understanding" (p.14). Rather than operate from concealed and predetermined agen- 
das, researchers should consider a paradigm shift that allows African-Americans to definetheir needs and health priorities. The community engagement model utilizes a "village" approach to inquiry and problem solving.

\section{Explaining the "Why" and the "What"}

Medical research campaigns must provide clear and understandable information to potential participants. Because of past experiences, African-Americans often feel justified in their negative perceptions and feelings of unfair treatment. Therefore, participants must clearly and truthfully be told the "why" as well as the "what" of their involvement in all verbal and written presentations. Croyle (1998) advises that researchers "make sure that what subjects are being told is consistent across the trial's stages-recruitment, consent and education, randomization and intervention-and across trial staff members" (p. 495). Research participants who received limited information decreased their participation. Conversely, when researchers provided people with detailed information concerning the nature of the research, the benefits, and research opportunities, recruitment results in ethnic populations were enhanced (Napoles-Springer, et al., 2000).

Target advertisements placed in newspapers and publications to recruit participants often emphasize the benefits of the trials without mentioning the risks. This is an identified concern and may raise questions about participants' level of understanding regarding what they are reading and subsequently signing. "Cash payments and other incentives are commonplace in medical research. But they are offered as compensation for a person's time, not as a fee for accepting risk. When you see an emphasis on cash payments and benefits, and little or no mention of risks, that's a real concern" (Weiss, 1998, p.A05). Napoles-Springer, et al. (2000) found that respondents sometimes subjected themselves to potentially harmful research and exploitation out of their dire need for money.

According to Napoles-Springer, et al. (2000) African-Americans greatly value scientific knowledge that will improve their quality of life. Additionally, if concerns are openly addressed, barriers to participation are reduced, and if tangible benefits of participation could be accrued by their communities, their interest in scientific knowledge will likely increase. Hatchett, et al. (2000) found that the failure of African-Americans to participate in research was not solely due to the legacy of the Tuskegee experiment but because they were not approached to be involved. Some African-Americans feel that researchers take information and ideas about AfricanAmericans out to the majority community without caring that those under study receive any significant or substantial benefit. In essence, some African-Americans feel that they are exploited or that researchers do not give back to their community (Napoles-Springer, et al., 2000). The willingness of African-Americans to participate in research seems strongly linked to whether or not the research has positive benefits and if participants are informed of the outcomes.

\section{Purposeful Community Relationships}

Leo J. O'Donovan (1998) describes trust as "being vulnerable and taking a risk-a leap of confidence-sometimes without any evidence that you will land on your feet" (p. 178). He emphasizes that the heart of a professional relationship is trust. For example, "We trust scientists and researchers will give us the right information 
as we care for our aging bodies. We don't question how exactly Tylenol or the Inderol we take works; we trust the medication to work-we trust the science behind it" (p. 180). Yet, the biggest obstacle to clinical trial recruitment is public wariness (Schoen, 1999). Participants need researchers that are reliable and trustworthy. A paradigm shift in public health and medical research necessitates that research volunteers are informed of the true state of their health and given full explanations about the benefits or dangers of any research intervention (Jennings, 1998). Only then can researchers begin to engender trust and recruit AfricanAmerican participants. Mistrust is real and it is serious. Are'an and GallagherThompson (cited in Hatchett, et al., 2000, p. 667) found that during recruitment efforts with older minority adults, "researchers' willingness to address specific topics of interests created an attitude of trust."

\section{Informed Consent}

Informed consent is, of course, related to the issue of trust. Bioethicist Arthur L. Caplan suggests that informed consent represents a moral challenge to researchers. Research participants should always have access to second opinions from experts who do not stand to gain from the outcome of the study (Jennings, 1998).The National Association of Social Workers' Code of Ethics addresses informed consent by prescribing that clients must be informed in clear and understandable language regarding purpose, risks, and limits of services, relevant costs, alternative to treatment, and the right to ask questions or to refuse or withdraw their consent for treatment (Linzer, 1999; NASW, 1996, 1.03).

Informed consent originated in the medical field as a mechanism for patients to receive detailed and pertinent information about medical procedures and their potential benefits and risks (Dunn, 2000; Linzer, 1999). Linzer (1999) indicates that social work practice includes a burden for informed consent that extends far beyond superficial efforts. Informed consent extends beyond obtaining signed release forms granting access to confidential information (Kutchins, 1991). This legal and ethical duty entails providing clients with full disclosure relative to all service or treatment areas, which can have an impact on the client's right to voluntarily participate or decline participation.

Therefore, it cannot be assumed that participants have given their full consent to participate in research studies until they receive full disclosure of all relevant information related to their participation. In cases where volunteers need support or assurance, Croyle (1998) advises involving family members in the informed consent process and recommends strategies for clarity in the consent process including the use of:

1. various font sizes, subheadings, and bullets in the consent form instead of long unbroken text;

2. printed materials as a backup, but with preference given to oral and aural communications to explain information; or

3. CD-ROM or audio tape presentations with the information to enhance volunteer understanding (p. 495). 


\section{Non-Traditional Culturally Sensitive Communications}

Traditional generic approaches to the promotion of medical research projects often proveto be ineffective (Mastin, 2000). Empirical evidence suggests that those with lower socioeconomic status and ethnically diverse populations appear to respond less to traditional recruitment methods (Mastin, 2000; Napoles-Springer, et al., 2000; Witte, et al., 1998). Non-traditional, culturally-sensitive communications that include the use of interpersonal networks (such as social gathering places, the Black church, neighborhood organizations, beauty salons, barbershops) and African-American celebrities to bring important public health information to the African-American community should be adopted (Mastin, 2000; Napoles-Springer, et al., 2000; Witte, et al., 1998).

In an effort to protect billions of investment dollars slated for new drugs, pharmaceutical companies are scrambling to recruit clinical participants for drug trials. Many of the newer drugs will offer cures for or better management of conditions such as high blood pressure, diabetes, AIDS, cancer, and cardiovascular disease. To shift the negative perception about clinical trials, the pharmaceutical industry must recognize the need for relevant community campaigns. Schoen (1999) indicates, "With all the pressure to implement trials and submit results quickly, companies sometimes treat effective communications as an after-thought, rather than a key strategic tool" (p. 51). Schoen further suggests providing videos, brochures, and other information to clinical sites in order to raise the level of awareness among African-Americans about disease.

The readability of written materials may also affect recruitment. Volunteers are not likely to risk embarrassment if they are semi-literate. Rather than succumb to shameand humiliation, it is sometimes a natural response to decline involvement in an activity in order to save face. Advertisements and other forms of promotional communications such as brochures, pamphlets, posters, letters, flyers, and banners have been proven more effective when written at fifth or sixth grade literacy levels (Burrus, et al., 1998). According to Fackelmann (1998), "about 90 million adults in the United States haveliteracy skills ranking below $7^{\text {th }}$ grade" $(p .15)$. Therefore, the readability level of written communication is an important consideration.

\section{SUMMARY OF RECOMMENDATIONS}

Participation in research efforts by African-American populations may be enhanced through a strengths-based and empowerment framework (Blundo, 2001; Brun \& Rapp, 2001; Early, 2001; Saleeby, 1996; Turner, 2001). The strengthsbased perspective is an empowerment approach that focuses on the strengths of individuals, families, and communities, rather than problems or pathology. Saleeby (1996) points out that the strengths approach requires an accounting of what people know and what they can do (p. 297). In a strengths approach, practitioners must engage individuals, families, and communities as equals. "They must be willing to meet clients eye to eye and to engage in dialogue and a mutual sharing of knowledge, tools, concerns, aspirations, and respect" (p. 303). Saleeby's perspective provides an explanatory framework that highlights that when communities are provided with information, resources, and support, helpers as well as community residents are likely to benefit. The principles that Saleeby (1996) believes 
particularly important to the strengths/empowerment perspective are: 1) language - the practice of using words to elevate or to lift and inspire; 2) empowerment-the process of assisting people to discover and to use the resources and tools within and around them; 3 ) resilience - the recognition that in spite of adversity, people accumulate skills, abilities, knowledge, and insight; 4) membershipthe idea of valuing individuals as part of a viable group or community; 5) health and wellness-the belief that people's innate resilience and knowledge can be used to help them overcome trauma and embrace community vitality; and 6) beliefs and emotions-the concept that personal health and emotions in the context of daily living can transcend to community health.

\section{RECOMMENDATIONS FOR CLIENT ENGAGEMENT}

A strengths-based empowerment perspective may be used as a foundation for researchers who hope to engage African-Americans in clinical trials or public health research. Recommended strategies include the following:

1. Approach African-Americans from an empowerment perspective, believing that they can provide and interpret relevant information about their needs and priorities and can offer their expertise to researchers.

2. Assume that African-Americans want to be included in relevant research and that because of the unequal distribution of power, opportunities, rights, and responsibilities, their voices often go unheard.

3. Convey a sense of reciprocity. Expect to receive ideas and cooperation and also expect to give something of value back to the community (e.g., briefings regarding the research outcomes, an ongoing community presence, donations to related causes, technical or professional assistance with identified concerns or requests for specific help, and so forth). In other words, avoid a one-way dynamic and being invisible until something is needed.

4. Honor the fiduciary relations. On a continuous basis, inform potential research volunteers of specific risks and benefits.

5. Protect research volunteers. It is imperative that researchers are reliable and trustworthy.

6. Increase the visibility of African-American researchers as well as African-American personalities within the community in all phases of research.

7. Create public forums within the African-American community in familiar and comfortable environments, where honest dialog about the nature of the research can occur.

8. Include representatives of the religious community in significant ways.

9. Maintain candid and regular dialogue and a willingness to listen to, instruct, and reassure participants.

10.Ensure that all written communications are compatible with the educational level of the participants. 
11.Identify places within the African-American community (such as churches, laundromats, beauty salons, barbershops, and social organizations) that would be promising places to recruit, distribute information, and educate the community about research campaigns.

\section{IMPLICATIONS FOR SOCIAL WORK EDUCATION}

The strengths-based empowerment perspective has implications and application for a broad range of professionals, including social work educators. "Historically, the social sciences, which includes the profession of social work, have negatively stereotyped African-Americans and most American social institutions have related to African-Americans from a white Anglo middle-class orientation" (Dhooper \& Moore, 2001, p. 123). Additionally, traditional social work curriculum has focused on disempowerment, deficits (problem focus), individual disorders, and/or pathology (Blundo, 2001; Saleeby, 1997). Similarly, a large percentage of agency field practicums followed a diagnosis and problem-focused orientation. The medical or pathology model was therefore reinforced for students in schools and in agency settings. The shift towards embracing clients' strengths, individually and collectively, means acknowledging that clients' are the best authorities in defining their tribulations. This is a transformational evolvement in social work education and practice. As social workers assist individuals and communities, they are challenged to use conceptual lenses that allow them to visualize people's hopes and dreams, based on their assets and strengths. Brueggemann (2002) asserts that:

People who experience injustice, intolerance, or economic or political oppression need to define their own issues on their own terms, regardless of the size of their group, their influence, their perception, or the approval of the majority of the population. When the influential usurp their right, they not only steal people's humanity but assume that people in the mass are incapable of understanding their own social situation; they exclude people from the process of making their own lives better. (p.43)

Blundo (2001) underscores this point of view and asserts that "the strengths perspective offers the profession an opportunity to change frames and to collaborate with individuals, families, and communities in a more egalitarian working relationship based upon their strengths and resilience" (p. 301). In social work practice, the use of the strengths and empowerment perspective with families can aid practitioners in identifying strengths to build on. They also increase their ability to gain knowledge regarding desired outcomes and clarity regarding what families want to achieve and under what conditions. This model relegates the "expert" from the position of "all-knowing" to a more equal position of partnering. Clients are positioned to share power, which permits them to demonstrate their strengths and resilience in a collaborative environment. In essence, this framework then prepares social workers to teach and to be taught.

\section{CONCLUSION}

The inadequate participation of African-Americans in research studies suggests implications that may negatively impact the understanding of health and social 
factors among this population. The challenge for researchers is to be more aware of how socioeconomic factors and racism may discourage African-Americans from participating in valuable research. In particular, social scientists need to be aware that fear, past medical and government practices, mistrust, and a lack of knowledge about bureaucratic practices are primary reasons that AfricanAmericans do not participate in research studies. Equally important is an understanding that mistrust of research is pervasive among African-Americans. Therefore, it seems reasonable to suggest that more concerted efforts to engage minority researchers, to address perceived and real barriers, and to improve awareness of racial and ethnic disparities would increase the level of African American participants in legitimate research studies. A strengths-based and empowerment approach allows individuals, families, communities, researchers, and other "helpers" to become co-participants with African-Americans to discover the power within themselves and to develop consensus in working as change agents.

\section{References}

Allen-Kelsey, G.J. (1998). Caregiver burden among African-American and Anglo-American family caregivers. Topics in Generic Rehabilitation, 14(1), 63-66.

Blundo, R. (2001). Learning strengths-based practice: Challenging our personal and professional frames. Families in Society, 82(3), 296-304.

Brueggemann, W.G. (2002). The practice of macro social work (2 ${ }^{\text {nd }}$ ed., rev.). Belmont, CA: Wadsworth.

Brun, C., \& Rapp, R.C. (2001). Strengths-based case management: Individuals' perspectives on strengths and the case manager relationship. Social Work, 46(3), 278-288.

Burrus, B., Liburd, L.C., \& Burroughs, A. (1998). Maximizing participation by black Americans in population-based diabetes research: The project direct pilot experience. Journal of Community Health, 23(1), 15-27.

Croyle, R. T. (1998). One investigator's tip for building patient trust. Journal of the National Cancer Institute, 90(7), 495.

Davidoff, F., DeAngelis, C.D., Drazen, J.M., Hoey, J., Hojgaard, L., Horton, R., Kotzin, S., Nicholls, M. G., Nylenna, M., Overbeke, A.; Sox, H. C., Van Der Weyden, M.B., \& Wilkes, M. S. (2001). Sponsorship, authorship, and accountability. The Lancet, 358(9285), 854-856.

Dhooper, S.S., \& Moore, S.E. (2000). Social work practice with culturally diverse people. Thousand Oaks, CA: Sage.

Dunn, D. (2000). Staff development special: Exploring the gray areas of informed consent. Nursing Management, 31(7), 20-25.

Dwyer, J.H. (1995). Genes, blood pressure and African-Americans. The Lancet, 346(8972), 392-393.

Early, T. (2001). Measures for practice with families from a strengths perspective. Families in Society, 82(3), 225-232.

Fackelmann, K. (1998). Informed consent-not. Science News, 154(1), 15.

Fairchild, A.L., \& Bayer, R. (1999). Uses and abuses of Tuskegee. Science, 284(5416), 919-921.

Flaskerud, J.H., \& Nyamathi, A.M. (2000). Attaining gender and ethnic diversity in health intervention research: Cultural responsiveness versus resource provision. Advances in Nursing Science, 22(4), 1-15.

Gamble, V.N. (1997). Under the shadow of Tuskegee: African-Americans and health care. American Journal of Public Health, 87(11), 1773-1778.

Grier, W. H., \& Cobbs, P.M. (1968). Black rage. New York: Basic Books. 
Harris, T. (1996). I heard it through the grapevine: Rumor in African-American culture. African American Review, 30(1), 117-119.

Hatchett, B., Holmes, K., Duran, D. A., \& Davis, C. (2000). African-Americans and research participation: The recruitment process. Journal of Black Studies, 30(5), 664-675.

Helmuth, L. (2000). NUH, under pressure, boosts minority health research. Science, 288(5466), 596-597.

Herbert, J.R., Hurley, T.G., Olendzki, B.C., Teas, J., et al.( 1998). Nutritional and socioeconomic factors in relation to prostate cancer mortality: A cross-national study. Journal of the National Cancer Institute, 90(21), 1637-1647.

Jennings, L. (1998). Rx for health professionals: Honesty, fairness, respect. TheFuturist, 32(8), $10-11$.

Kumanyika, S.K., Morssink, C.B., \& Nestle, M. (2001). Minority women and advocacy for women's health. American Journal of Public Health, 91(9), 1383-1388.

Kutchins, H. (1991). The fiduciary relationship: The legal basis for social workers' responsibilities to clients. Social Work, 36(2), 106-113.

Lilford, R.J., Braunholtz, D., Edwards, S., \&Stevens, A. (2001). Monitoring clinical trials-interim data should be publicly available. British Medical Journal, 323(7310), 441-442.

Linzer, N. (1999). Resolving ethical dilemmas. Needham Heights, MA: Allyn and Bacon.

Mastin, T. (2000). Media use and civic participation in the African-American population: Exploring participation among professionals and nonprofessionals. Journalism and Mass Communication Quarterly, 77(1), 115-127.

McWhorter, J.H. (2000). Losing the race: Self-sabotage in black America. New York, NY: The Free Press.

Napoles-Springer, A., Grumbach, K., Alexander, M., \& Moreno-John, G. (2000). Clinical research with older African-Americans and Latinos: Perspectives from the community. Research on Aging, 22(6), 668-691.

National Association of Social Workers. (1996). Code of Ethics. Washington, DC: Author.

National Institute of Drug Abuse (1998). Drugabuse among racial/ethnic minorities. (NIH publication No. 98-3888). Washington, DC: CSR Incorporated.

O’Donovan, L.J. (1998). A profession of trust: Reflections on a fundamental virtue. Vital Speeches of the Day, 64(6), 178-182.

Parsons, S., Simmons, W., Shinhoster, F., \& Kilburn, J. (1999). A test of the grapevine: An empirical examination of conspiracy theories among African-Americans. Sociological Spectrum, 19(2), 201-223.

Phillips, P. (1997). No plateau for HIV/AIDS epidemic in U.S. women. TheJournal of theAmerican Medical Association, 277(22), 1747-1749.

Raveis, V.H., \& Siegel, K. (1998). Factors associated with HIV-infected women's delay in seeking medical care. AIDS Care, 10, 549-562.

Reese, D.J., \& Ahern, R.E. (1999). Hospice access and use by African-Americans: Addressing cultural and institutional barriers through participatory action research. Social Work, 44, 549-560.

Ruffins, P. (1998). The Tuskeggee experiment's long shadow. Black Issues in Higher Education, 15(18), 2629.

Saleeby, D. (1996). The strengths perspective in social work: Extensions and cautions. Social Work, 4(3), 296-305.

Saleeby, D. (Ed.). (1997). Thestrengths perspective in social work practice ( $\left.2^{\text {nd }} \mathrm{ed}\right)$. New York: Longman.

Savitt, T.L. (1982). The use of Blacks for medical experimentation and demonstration in the old South. Journal of Southern History, 48, 331-348.

Schoen, L. (1999). Clinical trials' black eye. Pharmaceutical Executive, 19(12), 50-56.

Thomas, S.B., \& Quinn, S.C. (1993). Understanding the attitudes of Black Americans, In J. Stryker \& M. D. Smith (Eds.), Dimensions of HIV prevention: Needle exchange (pp. 99-128). Menlo Park, CA: Henry J. Kaiser Family Foundation.

Thompson, S.N., \& Chambers, J.W. (2000). African self-consciousness and health promoting behaviors among African American college students. Journal of Black Psychology, 26(3), 330-345. 
Turner C., \& Darity, W.A. (1973). Fears of genocide among Black Americans as related to age, sex, and religion. American Journal of Public Health, 63, 1029-1034.

Turner, S. G. (2001). Resilience and social work practice: Three case studies. Familiesin Society, 82(5), $441-448$.

Turner, P.A. (1993). I heard it through the grapevine: Rumor in African-American culture. Berkeley, CA: University of California Press.

U.S. Bureau of the Census. (2000). Total resident population by 5-year age groups, race, and Hispanic origin with special age categories: Middle series, 1999 to 2010. http:// www.census.gov/ population/www/ projections/ natsum-T3.htm

U.S. Bureau of the Census. (2001). Resident population estimates of theU.S. by sex, race, and Hispanic origin: April 1, 1990 to July 1, 1999, with short-term projection to November 1, 2000. http:// www.census.gov/population/ estimates/ nation/intfile3-1.txt.

Washington, H.A. (1994). Human guinea pigs. Emerge, 6(1), 24-35.

Weiss, R. (1998). Volunteers at risk in medical studies: Complex research projects strain system of safeguards series: Science on the ethical frontier. TheWashington Post, A1-A9.

Wilkinson, D.Y. (1974). For whose benefit? Politics and Sickle Cell. The Black Scholar, 5, 2631.

Witte, K., Berkowitz, J. M., Lillie, J. M., \& Cameron, K. A. (1998). Radon awareness and reduction campaigns for African-Americans: A theoretically based evaluation. Health Education and Behavior, 25(3), 284-303.

\section{Author's Note:}

Address correspondence to: Sharon E. Moore, Ph.D., Raymond A. Kent School of Social Work, University of Louisville, Louisville, KY 40292 USA. E-mail: semoor02@gwise.louisville.edu. 